\title{
Respons Pemberian Pupuk Hayati terhadap Peningkatan Produktivitas Kedelai di Lahan Rawa Pasang Surut
}

\section{The Response of Biofertilizer on Improving Soybean Productivity in Tidal Swampland}

\author{
Jumakir ${ }^{1}$, Endrizal ${ }^{1}$, dan Taufiq Abdullah ${ }^{2}$ \\ 1Balai Pengkajian Teknologi Pertanian Jambi \\ Jalan Samarinda Paal Lima Kotabaru-Jambi \\ ${ }^{2}$ Balai Penelitian Tanaman Aneka Kacang dan Umbi Malang \\ jumakirvilla@gmail.com
}

Diterima: 21 Juli 2020

Revisi: 22 Februari 2021

Disetujui: 31 Maret 2021

\begin{abstract}
ABSTRAK
Tujuan penelitian adalah untuk mengetahui pengaruh dan efektivitas pupuk hayati pada tanaman kedelai di lahan rawa pasang surut. Pengkajian dilaksanakan di Kelurahan Simpang, Kecamatan Berbak, Kabupaten Tanjung Jabung Timur, Provinsi Jambi pada Mei-Agustus 2017. Lahan yang digunakan adalah tipologi lahan sulfat masam potensial dan tipe luapan air $C$ dengan luas tanam 10 ha. Rancangan percobaan menggunakan Rancangan Acak Kelompok (RAK). Pupuk hayati yang digunakan yaitu empat pupuk hayati (Agrimeth, Provibio, Kedelai Plus, Agrisoy) dan kontrol tanpa pupuk hayati (cara petani) dengan 5 ulangan. Hasil pengkajian menunjukkan bahwa pupuk hayati meningkatkan pertumbuhan dan hasil kedelai pada lahan rawa pasang surut sebesar $0,25-0,70$ ton/ha atau $15,15-33,33$ persen dibanding tanpa pupuk hayati dan Provibio merupakan pupuk hayati paling efektif yang diindikasikan oleh hasil kedelai tertinggi 2,10 ton/ha.

kata kunci: kedelai, pupuk hayati, lahan rawa pasang surut
\end{abstract}

\section{ABSTRACT}

The research objective was to determine the effect and effectiveness of biological fertilizers on soybean plants in tidal swamps. The study was carried out in Simpang Village, Berbak sub-District, Tanjung Jabung Timur District, Jambi Province in May-August 2017. The land used was a potential acid sulfate land typology and type $C$ water overflow with a planted area of 10 ha. The experimental design used a randomized block design (RBD). The biological fertilizers used were four biological fertilizers (Agrimeth, Provibio, Soybean Plus, Agrisoy) and control without using biological fertilizers (farmer's method), done in five replications. The study showed that biological fertilizers increased growth and yield of soybeans in tidal swamplands by 0.25-0.70 tons/ha or 15.15-33.33 percent compared to soybeans without biological fertilizers. The most effective biofertilizer was Provibio, indicated by the highest soybean yield of 2.10 tons/ha.

keywords: soybean, biofertilizer, tidal swampland

\section{PENDAHULUAN}

ahan pasang surut mempunyai potensi -cukup besar untuk dikembangkan menjadi pusat pertumbuhan produksi pertanian berbasis tanaman pangan dalam menunjang ketahanan pangan nasional. Indonesia memiliki lahan pasang surut relatif luas, yaitu sekitar 20,1 juta ha dan 9,3 juta diantaranya mempunyai potensi untuk pengembangan tanaman pangan (Ismail, dkk., 1993; Alihamsyah, 2002). Lahan rawa ini sangat strategis dan penting bagi pengembangan pertanian sekaligus mendukung ketahanan pangan dan usaha agribisnis (Alihamsyah, 2002).

Provinsi Jambi diperkirakan memiliki lahan rawa seluas 684.000 ha atau sekitar 12 persen dari luas wilayahnya. Dari luasan tersebut yang telah dibuka dan direklamasi seluas 252.983 ha terdiri dari 211.962 ha lahan rawa pasang surut dan 41.021 ha lahan rawa lebak (lahan non pasang surut) (Bappeda Provinsi Jambi, 2016). Salah satu wilayah sentra kedelai di Kabupaten Tanjung Jabung Timur adalah Kecamatan Berbak dan Kecamatan Rantau Rasau. Budidaya kedelai umumnya menggunakan teknologi yang biasa 
dilakukan petani setempat dengan produktivitas sebesar 1,03 ton/ha (BPS, 2020). Dengan demikian masih tersedia peluang peningkatan produktivitas kedelai yang cukup besar.

Lahan sawah yang terus menerus dipupuk dengan takaran pupuk yang tinggi, menyebabkan terjadinya kemunduran produktivitas lahan sawah, baik kimia, fisika maupun biologi (Adiningsih, dkk., 1995). Pupukhayatimerupakan mikroorganisme hidup yang ditambahkan ke dalam tanah dalam bentuk inokulan atau bentuk lain untuk memfasilitasi atau menyediakan hara tertentu bagi tanaman. Pupuk hayati (biofertilizer) berfungsi memperbaiki biologi tanah, mengurangi penggunaan pupuk anorganik, dan ramah lingkungan (Syam, 2008; Yopie, dkk., 2012; Sumarno, dkk., 2012; dan Roidah, 2013). Penggunaan pupuk hayati tidak dapat menggantikan pupuk anorganik, tetapi dapat mengurangi takarannya karena kecukupan hara bagi tanaman bergantung pada tingkat kesuburan asli tanah atau inherent soil fertility status (Fagi, 2015).

Menurut Saraswati (2000), manfaat dari penggunaan pupuk hayati yaitu: (i) menyediakan sumber hara bagi tanaman; (ii) melindungi akar dari gangguan hama dan penyakit; (iii) menstimulasisistem perakaranagarberkembang sempurna sehingga memperpanjang usia akar; (iv) memacu mitosis jaringan meristem pada titik tumbuh pucuk, kuncup bunga, dan stolon; (v) sebagai penawar beberapa logam berat; (vi) sebagai metabolit pengatur tumbuh; dan (vii) sebagai bioaktifator. Selanjutnya Sanchez, dkk. (2011), mengemukakan bahwa pupuk hayati dapat meningkatkan ketersediaan unsur hara fosfat dan nitrogen serta meningkatkan pertumbuhan tanaman. Bakteri Azospirilum sp. berfungsi untuk menambat nitrogen dan menghasilkan hormon IAA (auksin), sehingga berpotensi sebagai plant growth promoter (Widawati dan Muharam, 2012), dan dapat berperan menginduksi gen sistem pertahanan tanaman terhadap penyakit (Yasuda, dkk., 2009).

Pupuk hayati memiliki keunggulan yaitu meningkatkan keanekaragaman dan aktivitas populasi mikroba tanah, memperbaiki struktur tanah, sebagai sumber hara, meningkatkan hasil tanaman, dan meningkatkan serapan hara oleh tanaman (Saraswati, 2000). Penggunaan pupuk hayati pada tanaman kedelai dapat memperbaiki kualitas tanah dan meningkatkan kandungan bahan organik (Saraswati, 2013; Harsono, dkk., 2012; dan Harsono, dkk., 2013). Pemanfaatan pembenah tanah pupuk hayati pada budidaya kedelai merupakan upaya memperbaiki struktur fisik dan biologi tanah sehingga akar tanaman dapat menyerap unsur hara lebih baik, yang akhirnya berdampak kepada pertumbuhan tinggi tanaman, jumlah daun, panjang akar, jumlah polong isi dan hasil biji kedelai.

Berbagai hasil penelitian mengindikasikan bahwa sebagian lahan pertanian intensif telah menurun produktivitasnya karena rendahnya kandungan C-organik, yaitu kurang dari 2,0 persen, bahkan banyak juga yang kurang dari 1,0 persen, padahal kandungan C-organik tanah untuk perolehan produktivitas optimal adalah lebih besar dari 2,5 persen (Suriadikarta dan Simanungkalit, 2006). Untuk memperoleh pertumbuhan dan hasil panen kedelai yang memadai, pupuk organik/kandang diperlukan dalam jumlah besar yakni 5-11 ton/ha (Hartatik dan Widowati, 2006), sehingga dalam penerapannya menghadapi permasalahan dalam pengadaan, pengangkutan, dan aplikasinya sebab banyak membutuhkan tenaga/biaya.

Badan Litbang Pertanian, LIPI, dan IPB telah menemukan berbagai pupuk hayati yang bersifat dekomposer bahan organik tanah, penambat nitrogen, penambang hara fosfor, hormon pemacu pertumbuhan, dan bakteri anti gangguan hama. Produk pupuk hayati tersebut adalah Agrisoy, Biovam, Kedelai Plus, Provibio dan Agrimeth. Berbagai produk tersebut telah dikaji keefektifannya di lahan masam dan non masam pada tanaman pangan. Diharapkan produk-produk tersebut secara ekonomis dapat meningkatkan produktivitas daripada teknik budidaya konvensional yang selama ini diterapkan petani.

Keefektifan pupuk hayati dalam meningkatkan hasil kedelai telah dilaporkan beberapa peneliti. Pupuk hayati lletrisoy-2 dan Rhizogin dapat meningkatkan hasil dari 1,10 ton/ha menjadi 1,94 ton/ha; penggunaan Ileytrisoy-2 + Santap 1,5 ton/ha meningkatkan hasil kedelai dari 1,10 ton/ha menjadi 1,82 ton/ha (Harsono, dkk., 2012 dan Harsono, dkk., 2013). Supriyo, dkk. (2014) mengemukakan bahwa aplikasi 
pupuk hayati F.1 dapat meningkatkan hasil kedelai 35,1 persen. Selanjutnya Sucahyono dan Harsono (2015) melaporkan hasil penelitian yang menunjukkan bahwa penggunaan pupuk hayati Provibio pada budidaya kedelai mampu meningkatkan hasil kedelai. Penggunaan pupuk hayati dapat meningkatkan hasil kedelai ratarata 0,5 ton/ha (Saraswati, 2013; Purwani dan Pratiwi, 2015). Hasil penelitian Astuti, dan Purba (2017), menunjukkan bahwa pupuk hayati Agrimeth $200 \mathrm{~g} / \mathrm{ha}+$ pupuk Gliocompost $20 \mathrm{~kg} / \mathrm{ha}+$ pupuk rekomendasi meningkatkan hasil kedelai dari 0,89 ton/ha menjadi 2,01 ton/ ha. Penambahan pupuk hayati pada tanaman kedelai dapat meningkatkan hasil 28,07-31,49 persen dibanding tanpa penambahan pupuk hayati (Jumakir, dkk., 2016). Tujuan penelitian adalah untuk mengetahui pengaruh dan efektivitas pupuk hayati pada tanaman kedelai di lahan rawa pasang surut.

\section{METODOLOGI}

\subsection{Pendekatan}

Pengkajian ini dilakukan dengan pendekatan partisipatif, melibatkan petani sejak perencanaan sampai evaluasi akhir kajian. Sebelum pengkajian, diawali dengan identifikasi permasalahan dan peluang pengembangan dengan pendekatan pedesaan secara partisipatif (Participatory Rapid Appraisal $=$ PRA). Pelaksanaan pengkajian berpedoman pada Panduan Pengkajian dan Diseminasi Teknologi Hasil Pengkajian yang diterbitkan Badan Litbang Pertanian 2014. Rancangan pengkajian mengintroduksi empat perlakuan pupuk hayati yaitu Agrimeth, Provibio, Kedelai Plus, dan Agrisoy dengan pembanding (kontrol) pola budidaya petani (tanpa pupuk hayati). Ulangan dalam pengkajian ini adalah petani yang jumlahnya mengacu pada formula: (n-1) $(\mathrm{t}-1) \geq 11$ (Balitbangtan, 2014).

\subsection{Tempat dan Waktu}

Lokasi pengkajian dipilih dan ditetapkan melalui pendekatan pemahaman pedesaan secara partisipatif $(P R A=$ Participatory Rapid Appraisal). PRA melibatkan tim peneliti/penyuluh BPTP Jambi, Dinas Pertanian Kabupaten Tanjung Jabung Timur, BP4K Kabupaten Tanjung Jabung Timur dan PPL serta petani calon kooperator. Lokasi yang dipilih adalah Kelurahan Simpang Kecamatan Berbak, Kabupaten Tanjung Jabung
Timur, Provinsi Jambi. Kegiatan pengkajian dilaksanakan pada musim kemarau (MeiAgustus) 2017 di lahan rawa pasang surut dengan tipologi lahan sulfat masam potensial dan tipe luapan air C.

\subsection{Metode}

Pengkajian ini menggunakan Rancangan Acak Kelompok terdiri dari empat perlakuan dan satu kontrol, yaitu: (i) $50 \mathrm{~kg} / \mathrm{ha}$ urea $+150 \mathrm{~kg} / \mathrm{ha}$ Phonska (Kontrol/pola petani); (ii) $50 \mathrm{~kg} / \mathrm{ha}$ urea + 150 kg/ha Phonska + Agrimeth; (iii) 50 kg/ha urea + $150 \mathrm{~kg} / \mathrm{ha}$ Phonska + Provibio; (iv) $50 \mathrm{~kg} /$ ha urea + $150 \mathrm{~kg} / \mathrm{ha}$ Phonska + Kedelai Plus; dan (v) $50 \mathrm{~kg} / \mathrm{ha}$ urea $+150 \mathrm{~kg} / \mathrm{ha}$ Phonska + Agrisoy.

Ulangan melibatkan 5 orang petani kooperator dan masing-masing petani kooperatormenerapkan lima perlakuan berdasarkan formula $(\mathrm{n}-1)(\mathrm{t}-1)>$ 11. Dengan $t=$ perlakuan, dan $n=$ ulangan.

Varietas kedelai yang ditanam adalah Anjasmoro dan jarak tanam $40 \mathrm{~cm} \times 15 \mathrm{~cm}$. Pembuatan/perbaikan saluran kemalir untuk pengaturan tata air agar tidak terjadi genangan air dan untuk proses pencucian dari unsur yang meracuni tanaman. Jarak tanam diatur untuk memudahkan dalam pemupukan, pengendalian gulma dan pengendalian OPT. Pemupukan dilakukan sesuai dengan perlakuan masing-masing. Seluruh takaran pupuk urea dan Phonska diberikan pada umur 10 HST. Pemberian pupuk dilakukan secara larikan sekitar 5-7 cm dari tanaman. Takaran pupuk hayati dan cara aplikasi dilakukan sesuai dengan SOP masing-masing produk pupuk hayati sebagai berikut :

Kedelai Plus (LIPI) yaitu biji kedelai diperkaya di laboratorium LIPI dengan bakteri pelarut fosfat, penghasil hormon tumbuh tanaman dan bakteri penambat nitrogen, dan selanjutnya dikemas untuk ditransfer ke lokasi penanaman. Sebelum tanam benih Kedelai Plus dicampur dengan Biovam (5 kg per hektar) dengan cara mencampur benih kedelai ke dalam bubur Biovam + yang telah disiapkan dalam suatu wadah. Bubur Biovam disiapkan dengan mencampur Biovam + dengan sedikit air agar merata menyerupai bubur. Benih kedelai plus yang sudah dilumuri dengan Biovam selanjutnya dapat ditanam seperti umumnya petani menanam kedelai, yakni 2 biji per lubang. 
Agrisoy (Balitbangtan) yaitu benih dimasukkan ke dalam ember, kemudian dibasahi dengan air secukupnya. Inokulan ditaburkan ke dalam benih (400 gram/40 kg benih/ha), diaduk sampai merata. Benih yang telah tercampur dengan inokulan Agrisoy diupayakan untuk tidak terkena cahaya matahari langsung agar tidak mematikan mikroba yang telah melekat pada benih, kemudian benih ditanam secara tunggal dan ditutup dengan tanah/pupuk organik. Agrisoy mengandung tiga jenis isolat bakteri penambat $\mathrm{N}$ (Bradyrhizobium) dan penambat $\mathrm{P}$.

Agrimeth (Balitbangtan) yaitu benih dimasukkan ke dalam ember, kemudian dibasahi dengan air secukupnya, inokulan ditaburkan ke dalam benih $(400 \mathrm{gr} / 40 \mathrm{~kg}$ benih/ha) diaduk sampai merata. Benih yang telah tercampur dengan inokulan Agrimeth diupayakan untuk tidak terkena cahaya matahari langsung agar tidak mematikan mikroba yang telah melekat pada benih, kemudian benih ditanam secara tunggal dan ditutup dengan tanah/pupuk organik. Agrimeth mengandung bakteri filosfer Methylobacterium sp. penghasil fitohormon.

Provibio yaitu provibio dilarutkan ke dalam air dan dilakukan penyemprotan pada tanaman umur 2, 4 dan 8 mingggu setelah tanam dengan dosis 7 liter/ha. Provibio mengandung bakteri bermanfaat yaitu Azospirillum lipoferum, Azotobacter vinelandii, Lactobacillus sp., Bradyrhizobium japonicum, Saccharomyces cerevisiae, Microbacterium lactum, Paenibacillus macerans dan Bacillus thuringiensis.

Data yang dikumpulkan meliputi: Karakteristik lokasi pengkajian dan aspek agronomis: (i) tinggi tanaman, diukur pada saat menjelang panen; (ii) jumlah cabang, dihitung cabang yang terdapat pada tanaman; (iii) jumlah polong, dihitung polong bernas/berisi pada tanaman; dan (iv) hasil biji kering setara kadar air 12 persen (ton/ ha). Hasil biji kering (ton/ha) diperoleh dari perhitungan hasil petak ubinan berukuran $2 \mathrm{~m} \times 5$ $\mathrm{m}$. Data yang diperoleh dianalisis menggunakan sidik ragam dan uji DMRT pada taraf 5 persen (Gomez and Gomez, 2007).

\section{HASIL DAN PEMBAHASAN}

\subsection{Karakteristik Lahan Pengkajian}

Kondisi lahan termasuk tipologi sulfat masam potensial, pada lapisan atas (sekitar $50 \mathrm{~cm}$ ) berwarna abu-abu dan bertekstur liat sedangkan pada lapisan di bawah 50 $\mathrm{cm}$ berwarna lebih cerah dan sudah keluar air. Kemungkinan tanah di lokasi pengkajian terbentuk dari hasil pengendapan sungai dan pada kedalaman $>50 \mathrm{~cm}$ terdapat lapisan pirit. Pada kedalaman 0-20 cm tanah termasuk gembur, namun pada kedalaman $>20 \mathrm{~cm}$ lapisan tanah keras.

Berdasarkan hasil pengkajian Taufiq, dkk. (2019), dari hasil analisis contoh tanah rawa pasang surut yang diambil pada kedalaman 0-20 cm diperoleh tanah yang tergolong masam, kandungan $\mathrm{C}$-organik rendah, $\mathrm{N}$ dan $\mathrm{P}$ tinggi, $\mathrm{K}$ dan $\mathrm{Mg}$ rendah, $\mathrm{Ca}$ tinggi, $\mathrm{Al}-\mathrm{dd}$ tinggi. Angka $\mathrm{pH}$ tanah rata-rata 5,2 (tergolong masam), kandungan C-organik 2,17-3,93 persen. Kandungan Kalium (K) sangat rendah $\left(0,15-0,26 \mathrm{cmol}^{+} / \mathrm{kg}\right)$, fosfor $(P)$ sangat rendah hingga sedang $\left(21,7-40,1 \mathrm{ppm} \mathrm{P}_{2} \mathrm{O}_{5}\right)$, Kalsium (Ca) rendah $\left(2,35-5,86 \mathrm{cmol}^{+} / \mathrm{kg}\right)$, Magnesium (Mg) rendah hingga sedang $\left(0,15-1,02 \mathrm{cmol}^{+} /\right.$ $\mathrm{kg}$ ). Kandungan Al-dd berkisar antara 0,63-1,47 $\mathrm{cmol}^{+} / \mathrm{kg}$, namun $\mathrm{H}-\mathrm{dd}$ sangat rendah. Sifat tanah

Tabel 1. Tinggi Tanaman dan Jumlah Cabang pada Pengkajian Pemberian Beberapa Pupuk Hayati di Lahan Rawa Pasang Surut Provinsi Jambi

\begin{tabular}{llcc}
\hline No. & \multicolumn{1}{c}{ Perlakuan } & $\begin{array}{c}\text { Tinggi Tanaman } \\
\text { (cm) }\end{array}$ & $\begin{array}{c}\text { Jumlah Cabang/ } \\
\text { Tanaman }\end{array}$ \\
\hline 1. Urea $50 \mathrm{~kg} / \mathrm{ha}$ dan Phonska $150 \mathrm{~kg} / \mathrm{ha}$ (Kontrol) & $55,67 \mathrm{a}$ & $2,40 \mathrm{a}$ \\
2. Urea $50 \mathrm{~kg} / \mathrm{ha}$, Phonska $150 \mathrm{~kg} / \mathrm{ha}$ dan Agrimeth & $56,33 \mathrm{a}$ & $2,90 \mathrm{ab}$ \\
3. Urea $50 \mathrm{~kg} / \mathrm{ha}$, Phonska150 kg/ha dan Agrisoy & $62,67 \mathrm{~b}$ & $3,20 \mathrm{~b}$ \\
4. Urea $50 \mathrm{~kg} / \mathrm{ha}$, Phonska150 kg/ha dan Kedelai & $68,33 \mathrm{c}$ & $3,70 \mathrm{~b}$ \\
& plus & $78,67 \mathrm{~d}$ & $3,60 \mathrm{~b}$ \\
5. Urea $50 \mathrm{~kg} / \mathrm{ha}$, Phonska150 kg/ha dan Provibio & 11,48 & 13,52 \\
\hline
\end{tabular}

$\overline{\text { Keterangan: Angka-angka yang diikuti oleh huruf yang sama tidak berbeda nyata pada taraf } 5 \text { persen DMRT }}$ 
demikian untuk bubidaya kedelai memerlukan tanah dengan $\mathrm{pH}$ netral dan kejenuhan $\mathrm{Al}$ maksimal 20 persen (Sumarno dan Manshuri, 2007). Batas kritis pH tanah untuk kedelai adalah 5,5 (Follet, dkk., 1981). Rendahnya pH tanah dan tingginya Al-dd menunjukkan retensi $P$ sehingga menurunkan ketersediaannya di lahan. Kandungan $\mathrm{P}$ tersedia $19,8 \mathrm{ppm}$, batas kritis untuk kedelai adalah 13,7-22,9 ppm $\mathrm{P}_{2} \mathrm{O}_{5}$ (Franzen, 2003).

\subsection{Pertumbuhan dan Hasil}

Hasil sidik ragam menunjukkan bahwa pemberian beberapa pupuk hayati berpengaruh nyata $(p<0,05)$ terhadap semua parameter yang diamati. Pertumbuhan tanaman kedelai pada fase vegetatif dan fase generatif menunjukkan rata-rata pertumbuhan cukup baik. Pemberian pupuk hayati Agrimeth, Provibio, Kedelai Plus dan Agrisoy umumnya menghasilkan pertumbuhan yang lebih baik dibanding cara petani (tanpa pupuk hayati).

Penambahan pupuk hayati menunjukkan pertumbuhan tinggi tanaman dan jumlah cabang lebih baik dibandingkan tanpa pupuk hayati (Tabel 1). Hal ini disebabkan pupuk hayati dapat meningkatkan ketersediaan hara dalam tanah, melindungi akar dari gangguan hama dan penyakit, menstimulasi sistem perakaran agar berkembang sempurna dan memperpanjang usia akar, mengatur tumbuh tanaman dan bioaktivator. Pupuk hayati dapat meningkatkan efisiensi pemupukan melalui perannya dalam menambat $\mathrm{N}_{2}$, melarutkan hara $\mathrm{P}$ dan $\mathrm{K}$, dekomposisi sisa tanaman dan transformasi hara, sehingga hara yang ada di dalam tanah menjadi lebih tersedia bagi tanaman (Saraswati, 2013).

Tabel 2. Jumlah Polong Isi dan Hasil Kedelai pada Pengkajian Pemberian Beberapa Pupuk Hayati di Lahan Rawa Pasang Surut Provinsi Jambi

\begin{tabular}{llcc}
\hline No. & \multicolumn{1}{c}{ Perlakuan } & $\begin{array}{c}\text { Jumlah Polong Isi } \\
\text { Per Tanaman }\end{array}$ & $\begin{array}{c}\text { Hasil } \\
\text { (ton/ha) }\end{array}$ \\
\hline 1. & Urea $50 \mathrm{~kg} / \mathrm{ha}$ dan Phonska $150 \mathrm{~kg} / \mathrm{ha}$ (Kontrol) & $45,50 \mathrm{a}$ & $1,40 \mathrm{a}$ \\
2. & Urea $50 \mathrm{~kg} / \mathrm{ha}$, Phonska $150 \mathrm{~kg} / \mathrm{ha}$ dan Agrimeth & $52,20 \mathrm{~b}$ & $1,65 \mathrm{ab}$ \\
3. & Urea $50 \mathrm{~kg} / \mathrm{ha}$, Phonska150 kg/ha dan Agrisoy & $62,00 \mathrm{c}$ & $1,75 \mathrm{~b}$ \\
4. & Urea $50 \mathrm{~kg} / \mathrm{ha}$, Phonska150 kg/ha dan Kedelai plus & $82,40 \mathrm{~d}$ & $1,90 \mathrm{bc}$ \\
5. & Urea $50 \mathrm{~kg} / \mathrm{ha}$, Phonska150 kg/ha dan Provibio & $83,30 \mathrm{~d}$ & $2,10 \mathrm{c}$ \\
& KK (persen) & 15,25 & 13,71 \\
\hline
\end{tabular}

Keterangan : Angka-angka yang diikuti oleh huruf yang sama tidak berbeda nyata pada taraf 5 persen DMRT 
mengemukakan bahwa komponen teknologi yang penting dalam meningkatkan produktivitas usaha tani kedelai adalah varietas anjuran, pemupukan, penggunaan pupuk kandang dan ameliorasi tanah

\section{KESIMPULAN}

Pemberian pupuk hayati pada tanaman kedelai di lahan rawa pasang surut memberikan pertumbuhan dan hasil kedelai lebih baik dibanding tanpa pupuk hayati, meningkatkan hasil sebesar $0,25-0,70$ ton/ha atau 15,1533,33 persen. Penambahan pupuk hayati Provibio memberikan hasil kedelai tertinggi yaitu 2,10 ton/ha.

\section{DAFTAR PUSTAKA}

Adiningsih, S.J., D. Setyorini, dan T. Prihatini. 1995. Pengelolaan hara terpadu untuk mencapai produksi pangan yang mantap dan akrab lingkungan. Hal 55-69. Pertemuan Teknis Penelitian Tanah dan Agroklimat: Makalah Kebijakan.Cisarua, Bogor, 10-12 Januari 1995. Pusat Penelitian Tanah dan Agroklimat,Badan Litbang Pertanian.

Alihamsyah, T. 2002. Optimalisasi pendayagunaan lahan rawa pasang surut. Seminar Nasional Optimalisasi Pendayagunaan Sumberdaya Lahan di Cisarua, 6-7 Agustus 2000. Puslitbang Tanah dan Agroklimat

Astuti, Y dan R. Purba. 2017. Respon Pertumbuhan dan Hasil Kedelai terhadap Pupuk Hayati di Lahan Sawah di Kabupaten Pandeglang, Banten. Agrovigor 10 (1) : 28-32

Balitbangtan. 2014. Panduan umum pengkajian dan diseminasi teknologi hasil pengkajian. Balai Besar Pengkajian dan Pengembangan Teknologi Pertanian. Kementan. Bogor

Bappeda Provinsi Jambi. 2011. Arah dan Kebijakan Pemanfaatan Lahan Rawa untuk Mendukung Surplus Beras di Provinsi Jambi. Materi disampaikan pada Rapat Dewan Ketahanan Pangan Provinsi Jambi Periode II. 15 Desember 2011. Jambi.

BPS. 2020. Provinsi Jambi dalam angka. BPS Jambi.

Fagi, A.M. 2015. Landasan Strategis Pembangunan Pertanian dan Peningkatan Produksi Pangan Berkelanjutan. Dalam. Sumbangan Pemikiran Strategi Pencapaian dan Pemantapan Kemandirian Pangan. Dilihat dari Aspek Sumber Daya, Kemiskinan, Penelitian, dan Penyuluhan: Refleksi 2001-2005. IAARD PRESS. 2015: 5-40.
Follet, R.H., L.S. Murphy and R.L. Donahoe. 1981. Fertilizers and Soil Amendments. Prentice Hall, Inc., London: 393-422.

Franzen, D.W. 2003. Soybean Soil Fertility. http// www.ext.nodak.edu/extpubs/plantsci/soilfert/ sf1164w.htm.

Gomez, K.A. and A.A. Gomez. 2007. Statistical Procedures for Agricultural Research with Emphasis on Rice. The International Rice Research Institute Los Banos Laguna. Philippiness.

Harmastini, S. dan D. Ariani 2010. Uji lapangan kedelai plus di Kelurahan Bleberan. Kecamatan Playen. Kabupaten Gunung Kidul. D.I Yogyakarta. Seminar Nasional Biologi 2010. "Perspektif Biologi dan Pengelolaan Sumberdaya Hayati". Fakultas Biologi Universitas Gadjah Mada Yogyakarta. 24-25 September 2010.

Harsono, A., Subandi, dan Suryantini. 2012. Formulasi Pupuk Hayati dan Organik Untuk Meningkatkan Produktivitas Aneka Kacang 20 Persen, Ubi 40 Persen Menghemat Pupuk Kimia 50 Persen. Laporan Hasil Penelitian Tahun 2010. Balitkabi. 53 halaman.

Harsono, A., Subandi, Hamastini, D. Santosa, dan A. Sariya. 2013. Kajian Keefektifan Pupuk Hayati pada Kedelai di Lahan Kering Masam. Laporan Kerjasama Badan Penelitian dan Pengembangan Pertanian dengan Komite Inovasi Nasional. 22 halaman.

Hartatik, W. dan L. R. Widowati. 2006. Pupuk kandang. P. 59-82. Dalam Simanungkalit, R.D.M., dkk (Ed.) Pupuk organik dan pupuk hayati. Balai Besar Litbang Sumberdaya Lahan Pertanian. Badan Litbang Pertanian.

Ismail, I.G, T. Alihamsyah, I.P.G. Widjaja Adhi, Suwarno, T. Herawati, R. Taher dan D.E. Sianturi. 1993. Sewindu Penelitian Pertanian di Lahan Rawa (1985-1993) Kontribusi dan Prospek Pengembangan. Swamps II. Badan Litbang Pertanian. Jakarta. 53 hal.

Jamal, H dan Jumakir. 2011. Faktor Penentu Produktivitas Kedelai di Lahan Pasang Surut Kabupaten Tanjung Jabung Timur Provinsi Jambi. Jurnal Pengkajian dan Pengembangan Teknologi Pertanian 14(1) : 49-61.

Jumakir, Endrizal dan Suyamto. 2016. Uji Beberapa Paket Pemupukan dan Dolomit terhadap Hasil Kedelai di Lahan Rawa Pasang Surut Provinsi Jambi. Jurnal Lahan Sub Optimal 5(1) : 85-93.

Latif, M.F., Elfarisna, dan Sudirman. 2017. Efektifitas Pengurangan Pupuk NPK dengan Pemberian Pupuk Hayati Provibio terhadap Budidaya Tanaman Kedelai Damame. Jurnal Agrosain dan Teknologi 2(2) : 105-120. 
Purwani, J. dan E. Pratiwi. 2015. Pengaruh Pupuk Hayati terhadap Pertumbuhan Dan Hasil Kedelai pada Ultisols Kabupaten Serang Di Rumah Kaca. Hal 155-162. Dalam Rahmianna, A.A., Sholihin, N. Nugrahaeni (Eds.). Prosiding Peran Inovasi Teknologi Aneka Kacang dan Umbi dalam Mendukung Program Kedaulatan Pangan. Malang 19 Mei 2015.

Roidah, I.S. 2013. Manfaat Penggunaan Pupuk Organik untuk Kesuburan Tanah. $J u r n$ a I Universitas Tulungagung, BONOROWO 1 (1): 30-42.

Sanchez, M.R., E. Armada, Y. Munos, I.E.G. de Salamon, R. Aroca, J.M.R. Lozano and R. Azcon. 2011. Azospirillumand ArbuscularMycorrhizal Colonization Enhance Rice Growth and Physiological Traits Under Well-Watered and Drought Conditions.J.of plant Physiol. 168:1031-1037

Saraswati, R. 2000. Peranan pupuk hayati dalam peningkatan produktivitas pangan. P. 46-54: Suwarno, et al. (Eds.): Tonggak Kemajuan Teknologi Produksi Tanaman Pangan: Paket dan komponen Teknologi ProduksiPadi. Simposium Penelitian Tanaman Pangan IV, Bogor, 22-24 November 1999. Pusat Penelitian dan Pengembangan Tanaman Pangan, Badan Penelitiandan Pengembangan Pertanian.

Saraswati, R. 2013. Potensi Penggunaan Pupuk Mikroba Secara Terpadu pada Kedelai. : 375381.Dalam Sumarno, Suyamto, A. Widjono, Hermanto, H. Kasim (Eds.). Kedelai Teknik Produksi dan Pengembangan. Badan Penelitian dan Pengembangan Pertanian, Pusat Penelitian dan Pengembangan Tanaman Pangan, Malang.

Sucahyono, D. dan A. Harsono. 2015. Keefektifan Pupuk Hayati di Lahan non Masam: 142- 150. Dalam Rahmianna, A.A., Sholihin, N. Nugrahaeni (Eds.). Prosiding Peran Inovasi Teknologi Aneka Kacang dan Umbi dalam Mendukung Program Kedaulatan Pangan. Malang 19 Mei2015.

Sumarno dan A.G. Manshuri. 2007. Persyaratan Tumbuh dan Wilayah Produksi Kedelai dilndonesia:74-103. Dalam Sumarno et al (Eds.). Kedelai: Teknik Produksi dan Pengembangan. Pusat Penelitian dan Pengembangan Tanaman Pangan. Bogor.

Sumarno, dan U.G. K artasasmita. 2012. Kesiapan Petani Menggunakan Pupuk Organik pada Padi Sawah. Jurnal Penelitian Pertanian Tanaman Pangan 31(3): 137-144.

Supriyo, A., S. Minarsih, dan B. Prayudi. 2014. Efektifitas Pemberian Pupuk Hayati terhadap Pertumbuhan dan Hasil Padi Gogo pada Tanah Kering. J.Agritech.16(1):1-12.
Suriadikarta, D.A. dan R.D.M. Simanungkalit. 2006. Pendahuluan, p. 1-10. Dalam: Simanungkalit et al. (Eds.). Pupuk Organik dan Pupuk Hayati. Balai Besar Litbang Sumberdaya Lahan Pertanian.

Syam, M. 2008. Padi Organik dan Tuntutan Peningkatan Produksi Beras.Jurnal I p $t$ e $k$ Tanaman Pangan 3(1): 1-8.

Taufiq, A., A. Wijanarko, A. Kristiono, S. Mutmaidah, N. Prasetiyaswati, dan Jumakir. 2019. Evaluasi Kelayakan Teknis dan Finansial Teknologi Budi Daya Kedelai pada Lahan Pasang Surut. Jurnal Penelitian Pertanian Tanaman Pangan 3 (2): 101-110

Widawati, S dan A. Muharam. 2012. Uji Laboratorium Azospirillum sp. yang Diisolasi dari beberapa Ekosistem. J. Hortikultura 22(30):258-267

Yasuda. M., S. Isawa, S. Shinozaki, K. Minamisawa and H. Nakasita. 2009. Effect of Colonization of Bacterial Endophyte, Azospirillum sp. B510 on Disease Resistance in Rice. Biosci. Biotec. Biochem. 7(12):1-5

Yopie, M., M.U. Harun, Munandar, R., Hayati, dan N. Gafa. 2012. Pemanfaatan Berbagai Jenis Pupuk Hayati pada Budidaya Tanaman Jagung (Zea Mays. L) Efisien Hara di Lahan Kering Marginal. Jurnal Lahan Suboptimal (1)1: 31-39.

Yoshida, S.1981. Fundamental of rice crop science. International Rice Research Institut. Manila.

\section{BIODATA PENULIS:}

Jumakir dilahirkan di Palembang, 13 Oktober 1966. Penulis menyelesaikan pendidikan S1 pada tahun 1991 Fakultas Pertanian Jurusan Budidaya Pertanian di Universitas Sriwijaya Palembang.

Endrizal di lahirkan di Batu Sangkar, 1 Januari 1958. Penulis menyelesaikan pendidikan S1 pada tahun 1983 Fakultas Pertanian Jurusan Budidaya Pertanian di Universitas Andalas Padang, dan S2 tahun 1998 Bidang Crop Science di Central Luzon State University Philippines.

Abdullah Taufiq di lahirkan di Jawa Timur, 13 Nopember 1962. Penulis menyelesaikan pendidikan S1 pada tahun 1987 Fakultas Pertanian Jurusan Kesuburan Tanah di Universitas Brawijaya Malang. S2 tahun 2001 Fakultas Pertanian Bidang Kesuburan Tanah di Universitas Gadjahmada Yogyakarta. 
Halaman ini sengaja dikosongkan 